UDC 341.637

DOI: 10.5937/RKSPP2101147J

MARKO JOVANOVIĆ

\title{
THE ROLE OF EX AEQUO ET BONO IN ICSID ARBITRATION
}

This article examines the role of the principle of ex aequo et bono in arbitration before the International Centre for Settlement of Investment Disputes (ICSID). At the outset, the author remarks that the cases in which the application of ex aequo et bono was agreed upon by the parties are very scarce. Nevertheless, despite that scarcity, it is possible to draw some conclusions on the way in which equity was invoked by the parties and applied by the ICSID tribunals. Two scenarios are analyzed in particular: the use of ex aequo et bono as the applicable framework for dispute settlement and the reliance on ex aequo et bono in an attempt to nullify the award before an ad hoc Committee. The author concludes that the reluctance of the parties to agree on ex aequo et bono may be explained by the lack of predictability of outcomes that is inherent to this source of law. On the contrary, it might be expected that the parties will continue trying to come up with creative arguments aimed at proving the unauthorized application of ex aequo et bono by the tribunals in their attempts to annul the awar$d$ on the basis of excess of powers.

Key words: investment arbitration, ICSID Centre, applicable law, ex aequo et bono, annulment

\section{INTRODUCTION}

One of the distinctive features of international arbitration is its ability to settle a dispute on the basis of ex aequo et bono - "according to what is equita-

Dr. Marko Jovanović, LL.M., Associate Professor, Faculty of Law, University of Belgrade, e-mail:marko.jovanovic@ius.bg.ac.rs. 
ble and good". This principle, the origins of which can be traced back to Roman law, ${ }^{1}$ allows the arbitrators to disregard the norms and rules of a specific national law and resolve the dispute in accordance with their sense of fairness, justice and good conscience. ${ }^{2}$ Since it replaces the otherwise applicable legal norms, ex aequo et bono is sometimes described as a "negative choice of law clause". ${ }^{3}$ Accordingly, the arbitrators must be specifically and explicitly granted the power by the parties to rely on ex aequo et bono so that this principle can gain the authority of a source of law for their dispute.

By allowing the arbitrators to resolve a dispute in accordance with their personal view of the right and just result, the concept of ex aequo et bono promotes and enhances the flexibility of arbitration as a dispute settlement method. As much as this is seen by some authors as a blessing to arbitration, because it helps this alternative dispute settlement method to avoid over-judicalisation, ${ }^{4}$ ex aequo et bono is at the same time its curse. Namely, since it is often misrepresented or misunderstood, ex aequo et bono is rarely chosen by the parties as a framework for settlement of their dispute. The uncertain content of ex aequo et bono gives rise to great caution and conspicuous reluctance of the parties in dispute with respect to the use of this concept. As noted by Lord Mustill, when the settlement of a dispute ex aequo et bono is agreed upon, the parties will have no idea of what their rights and duties may be until the arbitrators have spoken. ${ }^{5}$

Due to many questions, dilemmas and even mysteries that surround it, the concept of ex aequo et bono is still in the focus of interest of doctrine and practitioners alike. This applies not only to arbitration in general, ${ }^{6}$ but also to ICSID arbi-

1 For an overview of the development of the principle of ex aequo et bono as a source of law see Gerardo Broggini, "Réflexions sur l'Équité dans l'arbitrage international", ASA Bulletin, No. 2, 1991, 101-105, with further references.

2 Nobumichi Teramura, Ex Aequo et Bono as a Response to the 'Over-Judicalisation' of International Commercial Arbitration, Kluwer Law International, 2020, 9.

3 Wolfgang Peter, Arbitration and Renegotiation of International Investment Agreements, Kluwer Law International, 1995, 265, referring to Karl-Heinz Böckstiegel, Der Staat als Vertragspartner ausländischer Privatunternehmen, Athenäum Verlag, Frankfurt am Main, 1971, 249; HongLin Yu, "Amiable Composition - A Learning Curve", Journal of International Arbitration, No. 1, 2000, 81, referring to Lord Devlin, The Judge, Oxford University Press, Oxford, 1979, 92.

4 N. Teramura, op. cit., 2.

5 Lord Justice Michael Mustill, "Contemporary Problems in International Commercial Arbitration: A Response”, International Business Lawyer, No. 4, 1989, 163.

6 By way of example, an article on ex aequo et bono has been recently published in this very journal. See Milan Lazić, Guilio Palermo, Srđan Dragićević, "Ex Aequo et Bono in International Arbitration”, Revija Kopaoničke škole prirodnog prava, No. 1, 2020, 47-65. 
tration ${ }^{7}$. This article will attempt to add on to the ongoing research of ex aequo et bono by providing an analysis of the use of that concept in investment arbitration conducted under the auspices of the International Centre for Settlement of Investment Disputes (hereinafter: ICSID Centre). In order to do so, we will first describe and analyze the legal framework for the use of ex aequo et bono in ICSID arbitration. In that light we will study the available case law and finally try to draw the conclusions on the content meaning and use of ex aequo et bono before ICSID.

\section{LEGAL FRAMEWORK}

The legal basis for arbitration ex aequo et bono is found in Article 42 of the ICSID Convention. That provision governs the applicable law in ICSID proceedings and it reads as follows:

"(1) The Tribunal shall decide a dispute in accordance with such rules of law as may be agreed by the parties. In the absence of such agreement, the Tribunal shall apply the law of the Contracting State party to the dispute (including its rules on the conflict of laws) and such rules of international law as may be applicable.

(2) The Tribunal may not bring in a finding of non liquet on the ground of silence and obscurity of the law.

(3) The provisions of paragraphs (1) and (2) shall not prejudice the power of the Tribunal to decide a dispute ex aequo et bono if the parties so agree."

The wording of Article 42 of the ICSID Convention shows that the provision on equity contained in paragraph 3 can be analyzed both in relation to the provision on the applicable law (paragraph 1) and the provision on the prohibition of non liquet (paragraph 2). Both relations deserve a more detailed inspection. In addition, it should be explained how the parties can agree on ex aequo et bono.

\section{Ex aequo et bono and the applicable law}

When it is read in relation to Article 42(1), Article 42(3) of the ICSID Convention gives an alternative to the parties with respect to the choice of law. Not only are the parties free to choose the applicable rules of law for their dispute, but they can also agree to empower the tribunal to decide their case on an ex aequo et bono basis. Even though Article 42(3) of the ICSID Convention remains silent as to the specifics of ex aequo et bono, the commentators of the Convention make a

7 See Christoph Schreuer, "Decisions Ex Aequo et Bono Under the ICSID Convention”, ICSID Review - Foreign Investment Law Journal, Vol. 11, 1996, 37-63. 
clear conceptual distinction between the decision-making based on law (Article $42(1)$ ) and the decision-making based on equity (paragraph 3$).{ }^{8}$ This point is curious and significant, because it may appear to refer to the long-standing discussion on the exact extent of powers of the arbitrators acting ex aequo et bono. In the beginning, a distinction was made between ex aequo et bono and amiable composition. The former concept was understood as absolving the arbitrators of the duty to consider in any way the otherwise applicable law, leaving the resolution of the dispute entirely to their sense of justice, while the latter required them to start from the provisions of the otherwise applicable law, allowing them to depart from those provisions "correct" them only insofar as that was necessary to achieve the just solution. ${ }^{9}$ Nowadays the distinction between ex aequo et bono and amiable composition is generally seen as obsolete because the exact path used by the arbitrators to reach their solution bears little impact on the outcome of the proceedings - if the parties agreed on ex aequo et bono, their stipulation shall be respected if and only if the arbitrators have rendered a fair and just decision. The exact method that they used in order to render such a decision does not seem to be of importance, as long as the end-result is indeed 'fair and good'. Therefore, it may be concluded that the distinction between the decisions based on law and on equity is not made in relation to the method of establishing the content of $e x$ aequo et bono, but rather in relation to the limits that the arbitrators must respect when making their decision. When deciding a case on the basis of law, the arbitrators must stay within the limits of the applicable law, while when deciding on the basis of equity the arbitrators must respect the general boundaries set by the ius cogens, public policy and the ICSID Convention itself. ${ }^{10}$

In any event, the idea that the ICSID-administered arbitration should allow the decision-making on the basis of equity was approved since the beginning of the work on the text of the Convention and faced no noteworthy opposition throughout the drafting process. ${ }^{11}$ The text of the provision that was eventually adopted and that is now found in Article 42(3) of the ICSID Convention closely re-

8 Christoph Schreuer, Loretta Malintoppi, August Reinisch, Anthony Sinclair, The ICSID Convention - A Commentary, $2^{\text {nd }}$ edition, Cambridge University Press, Cambridge, 2009, 631.

9 William Park, "The Predictability Paradox Arbitrators and Applicable Law", The Application of Substantive Law by International Arbitrators (eds. Fabio Bortolotti, Pierre Mayer), Kluwer Law International, 2014, 66; Regis Bonnan, "Different Conceptions of Amiable Composition in International Commercial Arbitration: A Comparison in Space and Time", Journal of International Dispute Settlement, No. 3, 2015, 523.

10 See in that sense C. Schreuer, L. Malintoppi, A. Reinisch, A. Sinclair, op. cit., 631-632 and 637-638.

11 Ibidem, 632. 
sembles the Article 38(2) of the Statute of the International Court of Justice, ${ }^{12}$ which is understandable seeing the fact that the ICSID Convention is an international treaty and that one party in ICSID arbitration is necessarily a State. In addition, the text of Article 42(3) of the ICSID Convention is substantially similar to the provisions on ex aequo et bono in arbitration rules of the most prominent arbitration institution in the world. ${ }^{13}$ This resemblance shall allow to apply some of the some of the findings on ex aequo et bono made in commercial arbitration to the cases resolved before the ICSID Centre.

\section{Ex aequo et bono and non liquet}

The way in which the provision on ex aequo et bono is phrased in the ICSID Convention ("The provisions of paragraphs (1) and (2) shall not prejudice...") suggests that equity cannot serve as a gap-filling mechanism under the Convention. If a provision of the applicable law is not clear or understandable, it must be deciphered by using the interpretative rules and principles of interpretation that belong to that law. Likewise, if the applicable law contains lacunae, those should be filled in as predicated by the gap-filling mechanisms of that law.

This is consistent with the aforementioned opinion of the commentators of the ICSID Convention, pursuant to which the decision-making on the basis of law and the decision-making on the basis of equity form two separate realms. Therefore, it can be inferred that, under the ICSID Convention, ex aequo et bono is an autonomous framework for settlement of a dispute and it cannot be used as a "helping tool" when a dispute is supposed to be resolved in accordance with the law - either the one chosen by the parties or the one determined pursuant to the instructions laid down in Article 42(1) of the ICSID Convention.

\section{Agreement on ex aequo et bono}

Article 42(3) of the ICSID Convention unequivocally states that the parties must agree on the application of ex aequo et bono. The need for the existence of an

12 Article 38(2) of the ICJ Statute reads as follows: “This provision shall not prejudice the power of the Court to decide a case ex aequo et bono, if the parties agree thereto".

13 Cf. Art. 35(2) of the 2010 UNCITRAL Arbitration Rules; Art. 31.2 of the 2016 Arbitration Rules of the Singapore International Arbitration Centre; Art. 27(3) of the 2017 Arbitration Rules of the Arbitration Institute of the Stockholm Chamber of Commerce; Art. 24(4) of the 2018 Arbitration Rules of the German Arbitration Institute; Art. 36.2 of the 2018 Arbitration Rules of the Hong Kong International Arbitration Centre; Art. 22.4 of the 2020 Arbitration Rules of the London Court of International Arbitration; Art. 21(3) of the 2021 Arbitration Rules of the Arbitration Court of the International Chamber of Commerce. 
explicit agreement in order for the tribunal to be empowered to decide ex aequo et bono has been confirmed in case law. In AGIP v. Congo the respondent has proposed in its Counter-Memorial that the dispute be settled on the basis of equity. However, since the claimant has not accepted that proposal, the tribunal had to act in accordance with Article 42(1) of the ICSID Convention and apply the law specified in the arbitration agreement concluded between the parties. ${ }^{14}$

As much as the provision imposing the existence of an explicit agreement allowing the application of ex aequo et bono may seem clear at first reading, this requirement nevertheless invites some questions. Namely, it should be explained who are the parties to the agreement on ex aequo et bono and what should be the content of that agreement.

\section{Parties to the agreement}

The power of the arbitral tribunal to render a decision ex aequo et bono must be agreed upon by the parties. The question may arise as to who those parties are. ICSID arbitration is usually based on an international investment treaty concluded by States or other entities of public international law. Yet, the parties to the arbitral proceedings are the investor (the "beneficiary" of the international investment treaty) and the host State.

The systemic analysis of the use of the word "parties" in the ICSID Convention, and most notably its Article 25(1), ${ }^{15}$ which is the cornerstone of the jurisdiction of the Centre, leads to the conclusion that this term refers to the parties in dispute, i.e. the investor and the host State. This interpretation is confirmed in case law. For example, in Atlantic Triton v. Guinea, one of the early ICSID cases where the jurisdiction of the Centre was agreed upon in a contract between the investor and the host State, the two parties also stipulated that their dispute was to be resolved on the basis of equity. ${ }^{16}$

One could wonder if a reference to ex aequo et bono could nevertheless be included in the dispute settlement provisions of an international investment treaty. It seems to us that such an approach would hardly have any legal value. As ar-

14 AGIP v. Congo, ICSID Case No. ARB/77/1, Award, 30 November 1979, para. 44.

15 Art. 25(1) of the ICSID Convention reads as follows: "The jurisdiction of the Centre shall extend to any legal dispute arising directly out of an investment, between a Contracting State (or any constituent subdivision or agency of a Contracting State designated to the Centre by that State) and a national of another Contracting State, which the parties to the dispute consent in writing to submit to the Centre" (emph. added).

16 Atlantic Triton Company Ltd v. The People's Revolutionary Republic of Guinea, ICSID Case No. 84/1, Award, 21 April 1986, para. 2. 
gued above, the final say on the application of ex aequo et bono stays in the hands of the parties to the dispute by virtue of Article 42(3) of the ICSID Convention. Therefore, any potential reference to equity in an international investment treaty can therefore only have an informative or symbolic role, but it remains deprived of normative weight since the parties to the international investment treaty are not the parties to investment arbitration.

\section{Content of the agreement}

Article 42(3) of the ICSID Convention does not specify the content of the agreement on ex aequo et bono. It merely states that the power of the tribunal to decide the case on the basis of equity must be agreed upon by the parties. In order to assist the parties in formulating their agreement, ICSID has suggested a model clause. Namely, Model Clause 11 reads as follows: "Any Arbitral Tribunal constituted pursuant to this agreement shall have the power to decide a dispute ex aequo et bono". Concise and simple, this wording complies with the essential requirement set by Article 42(3) of the ICSID Convention - the explicit character of the agreement.

The Convention does not require that the dispute is entirely resolved on the basis of equity. Therefore, it is conceivable that the parties decide that only some of the disputed issues are resolved ex aequo et bono, while the others would remain to be settled in accordance with the applicable law. ${ }^{17}$ For example, due to its flexibility, equity may prove to be a particularly useful framework for assessing the damages in an investment arbitration, so the application of ex aequo et bono could be limited to that aspect of the dispute only. ${ }^{18}$

Also, it may happen that the parties combine the choice-of-law clause with the agreement on equity, thus leaving to the tribunal to decide whether it will decide the dispute in accordance with the applicable law or ex aequo et bono. That seems to have been the case in Atlantic Triton v. Guinea, where the parties decided that the applicable law was the Guinean law, while at the same time they agreed that their dispute should be resolved on the basis of equity, in accordance with Article 42(3) of the ICSID Convention. It was argued shortly after the enactment of the ICSID Convention that this methodological approach was desirable because it gives the possibility to the tribunal to choose the legal framework

17 See in that sense: C. Schreuer, L. Malintoppi, A. Reinisch, A. Sinclair, op. cit., 633.

18 Thomas Wälde, Borzu Sabahi, "Compensation, Damages and Valuation", The Oxford Handbook of International Investment Law (Eds. Peter Muchlinski, Federico Ortino, Christoph Schreuer), Oxford University Press, Oxford, 2008, 1104. 
which is the best suited for the dispute at hand, in light of all the relevant circumstances. ${ }^{19}$

By way a general observation, it may be concluded that the minimum requirement for admissibility of the parties' agreement on ex aequo et bono is that their choice is expressed in a clear and explicit way, no matter how simple or complex it may be. The Convention remains silent as to the other features of equity in ICSID arbitration, so it was left to case law to shed some more light on other aspects of ex aequo et bono.

\section{CASE LAW}

As shown above, the ICSID Convention only specifies that the parties must agree to empower the tribunal to act ex aequo et bono and that such agreement needs to be explicit. However, the proper analysis of the use of equity in investment arbitration, as in any other type of arbitration, invites many additional questions. Therefore, in order to understand better all important features of equity, it is necessary to examine the situations in which ex aequo et bono was invoked before ICSID tribunals.

The available case law shows that there are two characteristic situations in which ex aequo et bono is used before ICSID Centre. Firstly, the parties may decide that their dispute is resolved on the basis of equity. Secondly, one of the parties may attempt to argue that, by misapplying the law during the procedure on the merits, the tribunal actually decided the case ex aequo et bono without being authorized to do so, thus exceeding its powers, which could then constitute a ground for annulment of the award pursuant to Article 52(1)(b) of the ICSID Convention. Both of these situations should be discussed in more detail.

\section{Ex aequo et bono as the applicable framework for dispute settlement}

Just as in commercial arbitration, the parties before ICSID Centre are showing great caution with respect to the possibility of having their dispute resolved on the basis of equity. There are only two reported cases were the dispute was settled ex aequo et bono, both of them dating back to the early years of the ICSID Centre.

19 Chittharanjan Felix Amerasinghe, "Submissions to the Jurisdiction of the International Centre for Settlement of Investment Disputes", Journal of Maritime Law and Commerce, No. 2, 1974, 240. 
The first case where ex aequo et bono was applied was Benvenuti \& Bonfant $v$. Congo. Benvenuti \& Bonfant was an Italian company tasked by the Government of Congo to examine the building and operating in Congo of a factory for the manufacturing of plastic bottles. The two parties were supposed to establish a joint company for the production of plastic bottles in which the Italian partner would initially hold a $40 \%$ share (that share was later raised to $60 \%$ ). The problems between the partners started emerging already during the construction of the factory, they culminated after the factory started its operation and ended up with the nationalization of the company, i.e. the unlawful expropriation of the Italian partner's share. ${ }^{20}$ As it could not have been resolved otherwise, the dispute was brought before the ICSID Centre. The agreement between the parties did not contain a choice-of-law clause so the tribunal initially decided to determine the applicable law in accordance with Article 42(1) of the ICSID Convention. However, upon the commencement of the proceedings, the parties reached an agreement that their dispute should be resolved on the basis of equity, in accordance with Article 42(3) of the ICSID Convention. ${ }^{21}$ It should be noted, though, that the circumstances under which the parties agreed to ex aequo et bono were somewhat peculiar. Namely, at its preliminary meeting, the tribunal proposed to the parties to agree on equity, but the respondent refused that proposal. ${ }^{22}$ Nevertheless, during the proceedings, the parties attempted to make an additional effort to resolve their dispute amicably and in that light they sent a letter to the tribunal asking it “(...) not to render its decision before 30 August 1979 or, if it was impossible to reach an agreement before that date, to render its award as quickly as possible by judgment ex aequo et bono". ${ }^{23}$ Since the parties failed to reach an out-of-court settlement by the date indicated, the tribunal concluded that it was empowered to rule on the basis of equity. Indeed, the tribunal applied ex aequo et bono to all the crucial elements of the claim: compensation for damages arising out of unlawful expropriation of the claimant's share in the mixed company with respondent, compensation for moral damages, the interest rate and the determination of the date from which the interest started to run. ${ }^{24}$ In addition, the tribunal relied on ex aequo et bono when allocating the costs of arbitration and obliging the res-

20 S.A.R.L. Benvenuti \& Bonfant v. People's Republic of the Congo, ICSID Case No. ARB/77/2, Award, 8 August 1980, paras. 2.1-2.24.

${ }^{21}$ Ibidem, paras. 4.1-4.4.

22 Ibidem, paras. 1.5 and 1.6.

23 Ibidem, para. 1.22 .

${ }^{24}$ Ibidem, paras. 4.65-4.100. 
pondent to pay a special sum for compensating the additional costs that it caused by delaying the proceedings..$^{25}$ Therefore, with the exclusion of the somewhat specific circumstances under which the agreement on ex aequo et bono was reached, Benvenuti \& Bonfant $v$. Congo seems to have been a "textbook example" of the use of equity in ICSID arbitration.

The second case where ex aequo et bono was applied was Atlantic Triton $v$. Guinea. Atlantic Triton was a Norwegian company that was hired by the Guinean Ministry of Farming and Fishery to convert, equip and manage three fishing ships bought by Guinea. ${ }^{26}$ The parties failed to meet their contractual obligations and since the dispute could not have been settled amicably, the claimant relied on the dispute settlement provision contained in the contract and seized the ICSID Centre. As explained above, the contract contained a complex choice-of-law clause calling for the application of Guinean law as well as of ex aequo et bono. What is more, in the course of the proceedings the parties agreed that Guinean law was identical to French law on the day Guinea gained independence in 1958. Therefore, the tribunal interpreted this choice-of-law clause in the way that it had the possibility to choose whether it would resolve the dispute on the basis of Guinean (i.e. former French) law or on the basis of equity. Accordingly, in relation to the main claim the tribunal relied on its power to decide the case ex aequo et bono. That choice enabled it to reduce the sum due by the respondent to the claimant for the operation of the ships to less then one-third of the amount initially sought and it submitted the request for payment of the price for the reconstruction of the ships to the duty of the claimant to produce a bank guarantee and thus assure that the money would eventually be transferred to the shipyard hired to perform the reconstruction of the ships. ${ }^{27}$ With respect to the claim for interest, the tribunal decided to rely on the applicable law and set the interest rate at $9 \%$, as prescribed "(...) by the old Article 1154 of the French Civil Code still in force in Guinea".28

Both awards in which the tribunals applied ex aequo et bono were rendered in the times when ICSID decisions were not particularly long and elaborated. Unfortunately they do not offer much details regarding the way in which the tribunals understood the specifics of the principle of ex aequo et bono. Nevertheless, it may be observed that the tribunals paid a particular attention to the facts of the case and attempted to render an equitable solution in light of all the relevant cir-

25 Ibidem, paras. 4.124-4.129.

26 Atlantic Triton Company Ltd v. The People's Revolutionary Republic of Guinea, ICSID Case No. 84/1, Award, 21 April 1986, para. 2.

27 Ibidem, paras. 5 and 6.

28 Ibidem, para. 7. 
cumstances of the dispute. This is particularly noticeable in Atlantic Triton v. Guinea, where the tribunal could choose between the local law and ex aequo et bono. Upon a careful assessment of the facts of the case, the tribunal concluded that it would be equitable to apply the local law to the issue of interest, while the main claim was resolved on the basis of ex aequo et bono.

\section{Ex aequo et bono as a reason for annulment of the award}

As it has already been pointed out, if the ICSID tribunal were to resolve a dispute ex aequo et bono, it would have to be explicitly empowered by the parties to do so. In the absence of such agreement, the reliance on ex aequo et bono by the tribunal would constitute an excess of powers, which would in turn open the way for a possible annulment of the award on the basis of Article 52(1)(b) of the ICSID Convention. ICSID case law shows two possible scenarios under which the annulment of the award may be sought due to the unwarranted application of equity.

The first scenario would be the one where the tribunal would solve the dispute on the basis of ex aequo et bono without the parties' authorization. This seems to have been the case in Klöckner v. Cameroon. This dispute was (first) resolved by an award rendered in late 1983, by which the tribunal rejected both the claim and the counterclaim. ${ }^{29}$ A couple of months later, Klöckner applied for the annulment of the award stating, inter alia, that the tribunal applied ex aequo et bono without the agreement of the parties in that respect. More specifically, Klöckner put forward that the tribunal ought to have applied Cameroonian law based on French law, as required by the arbitration agreement, but it unjustifiably acted ex aequo et bono instead. Before proceeding to examine whether this allegation was well founded, the ad hoc Committee made a preliminary observation that the excess of powers may indeed consist in the non-application by the arbitrator of the rules contained in the arbitration agreement or in the application of the rules other than the ones agreed upon. This can happen in two emblematic situations: when the arbitrator applies local law while the arbitration agreement requires the application of equity, or when the arbitrator applies equity although he was required by the arbitration agreement to apply local law. ${ }^{30}$ Therefore, in the case at hand, the ad hoc Committee had to examine whether the tribunal actually resolved the dispute on the basis of ex aequo et bono rather than on the

${ }^{29}$ Klöckner v. Cameroon, ICSID Case No. ARB/81/2, Award, 21 October 1983, para. 196.

30 Klöckner v. Cameroon, ICSID Case No. ARB/81/2, Decision of the ad hoc Committee, 3 May 1985, para. 59. 
basis of the Cameroonian law. In doing so, the ad hoc Committee took particular note of the paragraph 107 of the Award, in which the tribunal stated that the principle of confidence, in the sense that a person must deal with its contractual partner in a frank, loyal and candid manner "(...) is a basic principle of French civil law, as is indeed the case under other national codes which we know of"31 (emph. added).

This passage posed two difficulties before the ad hoc Committee. First, the ad hoc Committee noted that the award referred to the principles of French law, rather than on its rules. Second, the ad hoc Committee was concerned with the fact that the tribunal did not state any legal grounds for its assertion that the duty of confidentiality was indeed a basic principle of French law, but it rather relied on "other national codes that it knows of".

As far as the first difficulty is concerned, the ad hoc Committee had to decide whether the reference to "the principles of French law" confirms that the tribunal had indeed acted in accordance with Article 42(1) of the ICSID Convention (which requires the tribunal to resolve the dispute in accordance with the law agreed upon by the parties or, in absence of such law, on the basis of the law of the host State and such rules of international law as may be applicable) or not. In other words, the question was whether the principle of confidentiality could qualify as a general principle of law and, as such, the applicable rule of international law in the sense of Article 42(1) of the ICSID Convention. Such conclusion could be made on the basis of Article 38(1)(c) of the Statute of the International Court of Justice, which proclaims the general principles of law recognized by civilized nations as one of the sources of international law. In the opinion of the ad hoc Committee, this would not be the correct application of Article 42(1) of the ICSID Convention. Namely, the ad hoc Committee maintains that the rules of international law have a dual role in the determination of applicable law under the ICSID Convention: complementary (in the sense that they can fill the lacunae in the local law) and corrective (in the sense that it can "cure" the non-conformity of the local law to the international law). ${ }^{32}$ In whatever of these two roles the international law should be invoked, the tribunal must first establish the content of the local law and inquire into it. ${ }^{33}$ Accordingly, the tribunal may not replace the local law by international law without even establishing and analyzing its provisions, nor can the local law be reduced to one single principle, no matter how general and fundamental that principle may be.

\footnotetext{
31 Ibidem, para. 66.

32 Ibidem, para. 69.

33 Ibidem.
} 
The second point of concern for the ad hoc Committee in the passage cited above was the reference to "other national codes". This reference further solidified the ad hoc Committee's impression that the tribunal actually relied on ex aequo et bono when resolving one of the disputed issues - the issue of full disclosure. It did not help that the tribunal stated that they "did not have the intention of applying new or exceptional legal principles to the turnkey operations only because they concern the projects which affect the economic and social development of a given State". ${ }^{34}$ On the contrary, in the very next sentence the tribunal put forward that "(...) it is particularly important that the universal rules requiring frankness and loyalty between the partners are respected (...)"35 (emph. added). These references to comparative law and universal principles of law, coupled with the failure of the tribunal to identify the legal basis for the duty of full disclosure in Cameroonian/French law, led the ad hoc Committee to conclude that the tribunal actually resolved the matter on the basis of ex aequo et bono, rather than on the basis of the law that ought to be applied in the case at hand. Consequently, the ad hoc Committee concluded that "(...) in its reasoning, limited to postulating and not demonstrating the existence of a principle or exploring the rules by which it can only take concrete form, the Tribunal has not applied 'the law of the Contracting State.' [It thus acted] outside the framework provided by Article 42(1), applying concepts or principles it probably considered equitable, acting as an amiable compositeur" ${ }^{36}$

A different scenario happened in several cases where one of the parties, dissatisfied with the way in which the tribunal applied the law determined on the basis of Article 42(1) of the ICSID Convention, attempted to prove that such (arguably) erroneous application of law amounted to resolution of the dispute ex aequo et bono. This was the case in Amco v. Indonesia, where Indonesia tried to prove that by misapplying the Indonesian law and by referring to "equitable considerations" in some parts of the award, the tribunal in fact resolved the dispute on the basis of equity, without being authorized by the parties to do so. However, the ad hoc Committee noted that the simple mentioning of "equitable considerations" does not automatically lead to the conclusion that the decision amounts to ex aequo et bono. ${ }^{37}$ Alongside this important observation, the ad hoc Committee

${ }^{34}$ Klöckner v. Cameroon, ICSID Case No. ARB/81/2, Award, 21 October 1983, para. 108.

35 Ibidem.

36 Klöckner v. Cameroon, ICSID Case No. ARB/81/2, Decision of the ad hoc Committee, 3 May 1985, para. 79.

37 Amco v. Indonesia, ICSID Case No. ARB/81/1, Decision of the ad hoc Committee, 16 May 1986, paras. 26, 28. 
emphasized the difference between the scrutiny of the application of law by the tribunal and the investigation whether the tribunal exceeded its powers in terms of the legal framework that it relied upon when resolving the dispute. In the words of the ad hoc Committee, the examination of the law applied by the tribunal is not done "(...) for the purpose of scrutinizing whether the Tribunal committed errors in the interpretation of he requirements of applicable law or in the ascertainment or evaluation of the relevant facts to which such law has been applied. Such scrutiny is properly the task of a court of appeals, which the ad hoc Committee is not. The ad hoc Committee will limit itself to determining whether the Tribunal did in fact apply the law it was bound to apply to the dispute. Failure to apply such law, as distinguished from mere misconstruction of that law, would constitute a manifest excess of powers on the part of the Tribunal and a ground for nullity under Article 52(1)(b) of the Convention"38 (emph added).

The idea that a reference to equitable considerations does not necessarily amount to a decision given on the basis of ex aequo et bono was further developed by the ad hoc Committee in MTD v. Chile. In this case as well the respondent alleged that the tribunal effectively decided some aspects of the dispute on an ex aequo et bono basis instead of on the basis of Chilean or international law, as required by Article 42(1) of the ICSID Convention. ${ }^{39}$ The ad hoc Committee made the following important distinction: "It should be noted that Article 42(3) of the ICSID Convention concerns the determination ex aequo et bono of disputes, i.e. of the substantial matter referred to the tribunal. This is different from taking into account consideration of fairness in applying the law. For example, individual rules of law will often require fairness or a balancing of interests to be taken into account". 40

The scrutiny of the application of ex aequo et bono in the ICSID case law reveals several important findings. First, the fact that the tribunal referred to equity or equitable considerations when rendering its decision does not automatically mean that such decision was given on the basis of ex aequo et bono. In order to establish whether the tribunal relied on the applicable law or on the equity, the ad hoc Committee must inspect the arbitral award. Nevertheless, such inspection should be limited to identifying the source of law used by the tribunal to resolve the dispute. In no way may this inspection turn into the assessment of correctness of the way in which the tribunal applied the law that it had relied upon, since the ICSID Convention does not offer a remedy for an improper application

38 Ibidem, para. 23.

39 MTD v. Chile, ICSID Case No. ARB/01/7, Decision on Annulment, 21 March 2007, para. 44.

40 Ibidem, para. 48. 
of law. Second, the ad hoc Committees recognized the difference between equity within the applicable law and equity as a source of law on its own (i.e. ex aequo et bono)..$^{41}$ The former relates to the way of application of the law determined on the basis of Article 42(1) of the ICSID Convention and thus the reliance on such "form" of equity does not constitute a breach of the tribunal's duty to apply the law selected by the parties or, in the absence of such choice, established on the basis of the subsidiary rule. On the contrary, the latter "form" of equity constitutes an autonomous source of law and in order to be allowed to rely upon it, the tribunal must be given the explicit authorization by the parties. Otherwise, the award risks to be annulled on the basis of Article 52(1)(b) of the ICSID Convention for the excess of powers by the tribunal, manifested in the breach of the parties' agreement as to the applicable law or the subsidiary rule for determining the applicable law contained in Article 42(1) of the ICSID Convention in fine. ${ }^{42}$ But how does one draw the line between these two "forms" of equity? How can the ad hoc Committee establish whether the equity was applied within the applicable law or as an autonomous source of law? It might be concluded from the available case law that the guidance should be sought in the statement of reasons for the award. If the tribunal succeeded in showing the legal grounds for relying on equity within the applicable law (by e.g. stating a provision of he applicable law which gives a discretionary power or leaves a margin of appreciation to the decision-maker), it is likely that the ad hoc Committee would find that the tribunal did not act ex aequo et bono. A failure by the tribunal to state precise legal grounds for invoking equity, as was the case in Klöckner v. Cameroon, is likely to lead to the opposite conclusion.

\section{CONCLUSION}

The available case law shows that ex aequo et bono might play a dual role in ICSID arbitration. Obviously, ex aequo et bono may be agreed upon by the parties as the source of law for the settlement of their dispute. While such agreement must be explicit, it is not subjected to any particular time limits - it may be reached even after the proceedings have begun. The second possible role of $e x$ aequo et bono in ICSID arbitration comes to effect in the annulment proceedings, when a party might attempt to prove that an unwarranted application of ex aequo

${ }^{41}$ For a discussion on differences between equity within the applicable law and ex aequo et bono see C. Schreuer, L. Malintoppi, A. Reinisch, A. Sinclair, op. cit., 636-637.

${ }^{42}$ For an explicit statement on this point see Maritime International Nominees Establishment (MINE) v. Republic of Guinea, ICSID Case No. ARB/84/4, Decision for Partial Annulment of the Award, 22 December 1989, para. 5.03. 
et bono by the tribunal constitutes the excess of its powers and thus opens the way for the annulment of the award on the basis of Article 52(1)(b) of the ICSID Convention. While it was accepted by the ad hoc Committees that the failure to apply the law determined on the basis of Article 42(1) of the ICSID Convention would indeed constitute a manifest excess of powers of the tribunal, an important difference was made between the misconstruction of the applicable law and the failure to apply that law. No matter how blatantly the applicable law may be misconstrued, its misconstruction could hardly lead to the conclusion that the tribunal in fact acted on the basis of ex aequo et bono. Nevertheless, it would not be appropriate to make any categorical observations in this respect, since the line between the misconstruction of the applicable law and the application of ex aequo et bono can sometimes be rather thin. Accordingly, the investigation must be made in each specific case, having in mind all the relevant circumstances of the dispute and the proceedings.

It appears that ex aequo et bono was rarely chosen by the parties as the applicable framework for the settlement of their dispute. Not only are the available cases scarce, but they also date back to the early years of the ICSID Centre. Lack of enthusiasm by the parties with respect to ex aequo et bono is a common trait between investment and commercial arbitration. Therefore, it might be safe to assume that the reason for such reluctance to choose this source of law is also similar - the fear of unpredictable outcomes of the dispute. If this assumption is true, it should be expected that the ICSID caseload on ex aequo et bono will remain scarce. It has been argued, though, at least in the context of commercial arbitration, that the legal problems arising out of the crisis caused by the CoVID-19 pandemic might call for more flexible approach in their settlement, which could open the way for a renaissance of ex aequo et bono. ${ }^{43}$ This expectation should be applied with some caution to investment arbitration, seeing its particular nature and the fact that the investor and the host State are not necessarily bound by a contract. In addition, some standards of investment protection, such as fair and equitable treatment, already leave enough discretionary power to the tribunals, so it seems that the reliance on ex aequo et bono would bring little added value, if any. On the contrary, it appears more realistic to expect that the parties will continue trying to come up with creative arguments aimed at proving the unauthorized application of ex aequo et bono by the tribunals in their attempts to annul the awards on the basis of excess of powers. That is, therefore, the field where new lessons on the way of operation of ex aequo et bono in the ICSID system might be learned.

${ }^{43}$ M. Lazić, G. Palermo, S. Dragićević, op. cit., 65. 
Dr MARKO JOVANOVIĆ

Vanredni profesor, Pravni fakultet

Univerzitet u Beogradu

\title{
ULOGA PRINCIPA EX AEQUO ET BONO U ICSID ARBITRAŽI
}

\author{
Rezime
}

\begin{abstract}
Ovaj rad ispituje ulogu principa ex aequo et bono u arbitraži pred Međunarodnim centrom za rešavanje investicionih sporova (ICSID Centrom). Autor najpre uočava da je broj predmeta u kojima su stranke ugovorile primenu principa ex aequo et bono izuzetno mali. Ipak, uprkos njihovoj malobrojnosti, ovi predmeti omogućavaju izvođenje određenih zaključaka u pogledu načina na koji su stranke ugovarale odlučivanje po pravičnosti i postupanja arbitražnih veća u takvim okolnostima. Posebno se razmatraju dva scenarija: primena ex aequo et bono kao merodavnog pravnog okvira za rešavanje spora i pozivanje na ex aequo et bono u pokušaju da se isposluje poništaj arbitražne odluke. Autor zaključuje da se oprez stranaka u pogledu ugovaranja odlučivanja po pravičnosti može objasniti strahom od nedovoljne predvidljivosti ishoda spora, što je nužna posledica mehanizma primene pravičnosti kao izvora prava. S druge strane, može se očekivati da će stranke nastaviti da pokazuju kreativnost u pokušaju da dokažu da pogrešna primena merodavnog prava u meritornom postupku pred arbitražnim većem zapravo predstavlja neovalšćeno odlučivanje ex aequo et bono, čime bi se otvorio put za poništaj takve arbitražne odluke zbog prekoračenja ovlašćenja arbitražnog veća.
\end{abstract}

Ključne reči: investiciona arbitraža, ICSID Centar, merodavno pravo, ex aequo et bono, poništaj arbitražne odluke

\section{Bibliography}

Amerasinghe C. F., "Submissions to the Jurisdiction of the International Centre for Settlement of Investment Disputes", Journal of Maritime Law and Commerce, No. 2, 1974.

Bonnan R., "Different Conceptions of Amiable Composition in International Commercial Arbitration: A Comparison in Space and Time", Journal of International Dispute Settlement, No. 3, 2015.

Broggini G., "Réflexions sur l'Équité dans l'arbitrage international”, ASA Bulletin, No. 2, 1991.

Lazić M., Palermo G., Dragićević S, “Ex Aequo et Bono in International Arbitration”, Revija Kopaoničke škole prirodnog prava, No. 1, 2020.

Mustill M., "Contemporary Problems in International Commercial Arbitration: A Response", International Business Lawyer No. 4, 1989.

Park W., “The Predictability Paradox Arbitrators and Applicable Law", The Application of Substantive Law by International Arbitrators (eds. Fabio Bortolotti, Pierre Mayer), Kluwer Law International, 2014. 
Peter W., Arbitration and Renegotiation of International Investment Agreements, Kluwer Law International, 1995.

Schreuer C., "Decisions Ex Aequo et Bono Under the ICSID Convention", ICSID Review Foreign Investment Law Journal, vol. 11, 1996.

Schreuer C., Malintoppi L., Reinisch A., Sinclair A., The ICSID Convention - A Commentary, $2^{\text {nd }}$ edition, Cambridge University Press, Cambridge, 2009.

Teramura N., Ex Aequo et Bono as a Response to the 'Over-Judicalisation' of International Commercial Arbitration, Kluwer Law International, 2020.

Wälde T., Sabahi B., "Compensation, Damages and Valuation", The Oxford Handbook of International Investment Law (Eds. Peter Muchlinski, Federico Ortino, Christoph Schreuer), Oxford University Press, Oxford, 2008.

Yu H.-L., "Amiable Composition - A Learning Curve", Journal of International Arbitration, No. 1, 2000.

Article history

Received: 04.05.2021.

Accepted: 18.05.2021.

ORIGINAL SCIENTIFIC PAPER 